\title{
Osteokalsin düzeylerinin adölesandaki büyüme atağını izleme ve büyüme potansiyelini belirlemedeki önemi
}

\section{The potential role of osteocalcin levels in growth monitoring during growth sprut of adolescents}

\author{
Halit Halil, ${ }^{1}$ (D) Erol Kınık ${ }^{2}$ \\ 'Sağlık Bilimleri Üniversitesi, Dr. Sami Ulus Kadın Doğum, Çocuk Sağlığı ve Hastalıkları Eğitim ve Araştırma Hastanesi, Ankara, Turkey \\ ${ }^{2}$ Hacettepe Üniversitesi, Çocuk Sağlığı ve Hastalıkları, Adölesan Bölümü, Ankara, Turkey
}

\section{Özet}

Amaç: Bu çalışmanın amacı boy uzamada hızlanma dönemine girmiş olabileceği düşünülen adölesanların cinsel gelişme evrelerine göre serum osteokalsin ve boy artışlarının arasındaki ilişkileri belirlemektir.

Gereç ve Yöntem: 23 erkek ve 21 kız olmak üzere toplam 44 vakanın yaş, cinsiyet ve cinsel gelişme evrelerine göre 6 ay süreyle boy ve osteokalsin artışlarına bakıldı.

Bulgular: Erkeklerin Tanner evre 3 ve 4, kızların evre 2 ve 3 osteokalsin düzeyleri yüksek bulundu. Erkeklerde evre 3 ve 4 arasında, kızlarda ise evre 2 ve 3 ile arasında ilişki yokken, erkeklerde evre 3+ 4 ortalama değerleri evre $5^{\prime}$ in ortalama değerlerinden daha yüksek bulunmuştur. Kızlarda ise evre $2+3$ ortalama değerleri evre 4'n ortalama değerlerinden daha yüksek bulunmuştur. Her iki cinste 6 ay süre ile boy ve osteokalsin artışları arasında anlamlı bir ilişki tespit edildi. (Erkeklerde $p=0.0088$, kızlarda ise $p=0.0053$ ). Boy artışı ile osteokalsin artışı arasında erkeklerde \%53, kızlarda ise \% 59.8'lik pozitif bir ilişki bulundu. Boy artışında meydana gelen değişikliklerin erkeklerde \%28.4, kızlarda ise \%35.8'inin osteokalsin ile açıklanabileceği sonucuna varıldı. Geç puberte döneminde erkeklerde evre 4 ten 5'e geçerken, kızlarda ise evre 3 ten 4'e geçerken boy ve osteokalsin artışlarında ve ortalama osteokalsin düzeylerin de belirgin bir düşüş gözlendi. Her iki cinste erkeklerde evre 5, kızlarda ise evre 4 değerleri ile bir önceki evrelerin değerleri arasında belirgin fark gözlendi.

Sonuç: Boy uzamada hızlanma dönemine giren adölesanların birbirini izleyen osteokalsin ölçüm değerlerinin, bireyin pubertal büyüme grafiğindeki yerini saptama ve boyca uzama ile ilgili yorumda bulunma için yardımcı olabileceğini kanısına varıldı.

Anahtar Sözcükler: Adolesan; cinsel gelişme evreleri; osteokalsin.

\begin{abstract}
Introduction: We aimed to determine the relationship between the increase in body length and serum osteocalcin level according to sexual maturation stage of adolescents during pubertal growth spurt period.

Methods: Twenty three male and 21 female adolescent were included in our study. Serial body length and serum osteocalcin levels were recorded during the 6 month study period.

Results: Seum osteocalcin levels were high in sexual maturation stages 3 and 4 of male and 2 and 3 of female adolescents. There were no difference between sexual maturation stages 3 and 4 of males and 2 and 3 of female adolescents. However, the mean osteocalcin levels of stage $3+4$ of males were higher than stage 5 . We also found that mean osteocalcin levels of stage $2+3$ of females were higher than stage 4 . During the 6 month study period, there was a positive relationship between the raise in body length and serum osteocalcin levels. $53 \%$ in males and $59.8 \%$ in females. (males $p=0.0088$, females $\mathrm{p}=0.0053$ ). The change in body length can be explained by osteocalcin in $28.4 \%$ of males and $35.8 \%$ of females.As males pass from stage 4 to 5 and females from stage 3 to 4 the raise in body length and serum osteocalcin levels strat to decrease and finally were found to be lower than the previous stages.

Discussion and Conclusion: We conclude that the serial serum values of osteocalcin can help us to adjust the body length of adolescents on the body growth curve.
\end{abstract}

Keywords: Adolescents; osteocalcin; sexual maturation stage. 
$\mathrm{O}$ steoblastlar tarafından sentezlenen osteokalsin, kemik metabolizmasının değerlendirilmesinde non-invaziv ve spesifik bir belirleyicidir. ${ }^{[1]}$ Serum osteokalsin düzeyi yüksek kemik dönüşümü ile karakterize durumlarda artar, büyüme atağının (Growth Spurt) gerçekleştiği puberte buna iyi bir örnektir. ${ }^{[2-4]}$ Adölesandaki en önemli değişimlerden biri hızlı fiziksel büyümedir. Boyca büyüme hızındaki artış kızlarda 10, erkeklerde 12 yaşta başlayarak kızlarda cinsel gelişme evresi 3 veya 12 yaşta, erkeklerde cinsel gelişme evresi 4 veya 14 yaşta doruk noktasına (Peak Height Velocity) ulaşır, daha sonra hız giderek azalır ve büyüme sonlanır. ${ }^{[5-8]}$ Bu yaşlarda boyca uzama atağı, osteokalsin seviyesi de osteoblastik aktiviteyle birlikte artar. Kemik dönüşümü ise maksimum seviyeye ulaşmak için hızlanır, geç puberte dönemlerinde ise lineer büyüme hızındaki yavaşlama ve epifiz matürasyonunun tamamlanması ile birikte azalır. ${ }^{[9-11]}$

Bu çalışmanın amacı boy uzamada hızlanma dönemine girmiş olduğu düşünülen erkek ve kız adölesanların seri serum osteokalsin seviyeleri ile yaş, kemik yaşı, cins ve cinsel gelişme evreleri arasındaki ilişkileri belirlemektir. Osteokalsin düzeylerindeki birbirini izleyen artma veya azalma bulgularının bireyin büyüme hızı grafiğindeki yerini belirlemede etkinliğinin değerlendirilmesi amaçlanmıştır.

\section{Gereç ve Yöntem}

Çalışma Hacettepe Üniversitesi Tıp Fakültesi Adölesan polikliniğine başvuran yaşları 12 ile 16 arasında değişen 23 erkek ve 11 ile 14 arasında değişen 21 kız çocukta yapılmıştır. Çaısşmaya dahil edilme kriterleri olarak, sağlıklı olup büyümesinin normal sınırlarda olması, doğuştan iskelet anomalisinin olmaması, metabolik hastalığı olmaması, kalsiyum metabolizmasını etkileyen herhangi bir ilaç alımı öyküsünün olmaması, başta böbrek veya gastrointestinal hastalık olmak üzere herhangi bir sistemik hastalık öyküsünün olmaması, her iki cins için takvim yaşı ile kemik yaşının eşit olması kabul edilmiştir.

Seçilen adölesan vakaların sol el bilek ve parmaklarının röntgen filmleri çekilmiş, kemik yaşları Greulich ve Pyle metoduna göre değerlendirilmiştir. ${ }^{[12-13]}$ Puberte büyüme atağının başladığı düşünülen; kemik yaşı kızlarda en az 11, erkeklerde ise 12 olanlar çalışmaya dahil edilmişti. ${ }^{[5]}$

Çalışmaya dahil edilen adölesanların sistemik fizik muayenesi yapılıp ağırlık ve boyları ölçülmüştür ve her iki cinste Tanner kriterlerine göre cinsel gelişme evresi belirlenmiş, testis volümü ölçmek için Prader'in orşidometresi kullanılmıştır. ${ }^{[14]}$

Vakaların takvim ve kemik yaşları 'ay', cinsel gelişme evreleri 'Tanner Kriterleri, $\left.{ }^{\prime}, 15\right]$ boy ' $\mathrm{cm}$ ' ve osteokalsin 'ng/ml' olarak ifade edilmiştir. Boy ve osteokalsin ait değerler ilk gelişte (1), 3 ay sonra (2) ve 6. ay (3) rakamı ile belirtilmiştir.

Araştırmamıza dahil edilen hastaların toplam $3 \mathrm{kez}$ olmak üzere $0 ., 3$., ve 6 . aylarda boy uzunlukları ve serum osteokal- sin düzeylerinin belirlemesi için her vakadan $5 \mathrm{ml}$ kan örneği alınmıştır. Plazma osteokalsin düzeyinin sirkadien ritmi olduğu için tüm örnekler sabah 08-09 saatleri arasında aç olarak alınmıştır. Kanlar oda sıcaklığında 30 dakika pıhtlaşmaya bırakılmıștır ve santrifuj sonrası osteokalsin düzeyleri ELISA yöntemi (ELISA kiti: Novo Metra Biyosystems) ile tespit edilmiştir. ${ }^{[16]}$ Osteokalsinin kantitif değerleri ng/ml (nanogram/mililitre) olarak ölçülmüştür.

İstatistiksel analizisi için SPSS 17.0 versiyonu (Statistical Package for Social Sciences, SPSS Inc, Chi- 106 cago, IL) programı kullanılmıştır. Her iki cinste cinsel gelişme evreleri arasında ortalama osteokalsin düzeyleri arasında farklılığına Mann Whitney-U test ile bakılmıştır. Altı aylık süredeki ortalama boy artışı ile osteokalsin düzeyleri artış arasındaki ilişki ise regresyon Analizi Test ile incelenmiştir.

\section{Bulgular}

Boy uzamada hızlanma dönemine giren 23 erkek ve 21 kız olmak üzere toplam 44 vaka çalışmamıza dahil edilmiştir. Vakaların elde edilen verileri; cins, yaş ve cinsel gelişme evrelerine göre 6 ay süreyle boy ve osteokalsin değerleri Tablo 1'de gösterilmiştir.

Çalışmaya dahil edilen vakaların ortalama takvim ve kemik yaşı \pm standard hataları sırasıyla erkeklerde $13.98 \pm 0.73$ ve $13.97 \pm 0.73$, kızlarda ise $12.76 \pm 0.72$ ve $12.76 \pm 0.78$ yıldır.

Başlangıçtaki ortalama serum osteokalsin \pm standard hata erkeklerde $22.92 \pm 7.79$ kızlarda ise $19.22 \pm 9.40 \mathrm{ng} / \mathrm{ml}$ olarak bulunmuştur (Tablo 2).

Erkeklerde ortalama doruk serum osteokalsin düzeylerini Tanner evre 3 ve 4 'te sırasıyla $26.1 \pm 2.32$ ve $27.9 \pm 1.92 \mathrm{ng} / \mathrm{ml}$, kızlarda ise ortalama doruk osteokalsin düzeylerini Tanner evre 2 ve 3'te sırasıyla $25.3 \pm 4.27$ ve $22.8 \pm 2.4 \mathrm{ng} / \mathrm{ml}$ olarak saptadık. Geç puberte döneminde erkeklerde Tanner evre 4 ten $5^{\prime} \mathrm{e}$, kızlarda ise Tanner 3 ten 4'e geçerken osteokalsin artışlarında belirgin bir düşüş gözlendi. Erkeklerde Tanner evre 5'te $17.2 \pm 0.83 \mathrm{ng} /$ $\mathrm{ml}$, kızlarda ise Tanner evre 4'te $13.5 \pm 3.16 \mathrm{ng} / \mathrm{ml}$ 'ya kadar düştüğü tespit edildi (Tablo 3).

Boy uzama atağı sırasındaki altı aylık sürede ortalama boy ve osteokalsin artışları erkeklerde sırasıyla $3.56 \pm 1.807 \mathrm{~cm}$ ve $7.08 \pm 5.4 \mathrm{ng} / \mathrm{ml}$ kızlarda ise $3.61 \pm 0.99 \mathrm{~cm}$ ve $7.46 \pm 4.18 \mathrm{ng} / \mathrm{ml}$ olarak bulundu. Geç puberte döneminde erkeklerde Tanner evre 4 ten 5'e, kızlarda ise Tanner 3 ten 4'e geçerken boy ve osteokalsin artışlarında belirgin bir düşüş gözlendi (Tablo 3).

Her iki cinste boy uzama atağı sırasında boy uzama artarken osteokalsin düzeyinde de artış gözlendi (Tablo 4, Şekil 1, 2).

Geç puberte döneminde erkeklerde Tanner evre 4 ten 5'e, kızlarda ise Tanner 3 ten 4'e geçerken boy uzama ve osteokalsin artışlarında belirgin bir düşüş gözlendi. Erkeklerde evre $3+4$ ile 5 , kızlarda ise evre $2+3$ ile 4 arasında anlamlı bir fark olduğu tespit edildi. 
Tablo 1. Her iki cinste: başlangıçdaki, takvim ve kemik yaşı, cinsel gelişme evreleri, boy ve osteokalsin değerleri (ng/ml), 3 ve 6 ay sonra boy ve osteokalsin değerleri (ng/ml)

\begin{tabular}{|c|c|c|c|c|c|c|c|c|c|}
\hline No & Yaş (yıl) & KY (yıl) & CGE & Boy 1 & Ost. 1 & Boy 2 & Ost. 2 & Boy 3 & Ost. 3 \\
\hline 1 & 14.25 & 14.50 & 4 & 169 & 29.3 & 170 & 28.4 & 172 & 28.2 \\
\hline 3 & 13.42 & 13.50 & 3 & 143.5 & 18.5 & 145 & 24.2 & 148 & 28.6 \\
\hline 4 & 14.75 & 14.50 & 4 & 160 & 31.2 & 162 & 36.8 & 165 & 39.7 \\
\hline 7 & 14.67 & 14.50 & 4 & 162 & 14.4 & 163 & 18.6 & 166 & 31.4 \\
\hline 8 & 14.67 & 14.50 & 4 & 165 & 16.3 & 167 & 21.8 & 169 & 32.4 \\
\hline 9 & 13.17 & 13.50 & 4 & 165 & 33.6 & 166 & 34.8 & 168 & 38.4 \\
\hline 10 & 14.00 & 14.00 & 4 & 159 & 15.4 & 161 & 17.2 & 163 & 25.1 \\
\hline 11 & 14.92 & 15.00 & 5 & 175 & 16.2 & 176 & 15.3 & 176 & 16.4 \\
\hline 15 & 13.08 & 13.00 & 3 & 155 & 32.5 & 157.5 & 30.3 & 159 & 34.6 \\
\hline 16 & 14.33 & 14.50 & 3 & 163 & 13.5 & 165 & 19.1 & 167 & 28.8 \\
\hline 17 & 15.00 & 15.00 & 5 & 169 & 18.5 & 170 & 18.6 & 170 & 19.3 \\
\hline 18 & 14.33 & 14.50 & 4 & 155 & 17.1 & 157.5 & 19.6 & 159.5 & 26.4 \\
\hline 19 & 13.00 & 13.00 & 4 & 175 & 19.9 & 176 & 22.5 & 178 & 30.1 \\
\hline 20 & 13.75 & 13.50 & 4 & 158 & 18.6 & 160.5 & 27.6 & 162 & 30.1 \\
\hline 21 & 14.00 & 14.00 & 4 & 165 & 33.8 & 166 & 36.2 & 168 & 38.5 \\
\hline 22 & 14.00 & 14.00 & 4 & 154 & 39.6 & 156 & 37.1 & 158 & 39.8 \\
\hline 23 & 13.17 & 13.00 & 3 & 146 & 29.4 & 150 & 33.6 & 151 & 38.2 \\
\hline \multicolumn{10}{|l|}{ Kızlar } \\
\hline 7 & 13.25 & 13.50 & 4 & 154 & 14.2 & 156 & 17.9 & 156 & 18.1 \\
\hline 8 & 13.08 & 13.00 & 3 & 154 & 14.3 & 156 & 13.2 & 158 & 18.7 \\
\hline 9 & 11.75 & 12.00 & 2 & 157 & 35.5 & 158 & 38.1 & 160 & 39.8 \\
\hline 10 & 11.42 & 11.50 & 2 & 146 & 35.3 & 148 & 38.4 & 151 & 39.5 \\
\hline 11 & 11.17 & 11.00 & 2 & 162 & 16.2 & 164 & 21.5 & 167 & 28.1 \\
\hline 12 & 13.75 & 13.83 & 3 & 163 & 7.4 & 165 & 10.6 & 166 & 10.7 \\
\hline 13 & 12.25 & 12.50 & 3 & 152 & 34.7 & 153 & 38.7 & 156 & 36.4 \\
\hline 14 & 13.25 & 13.50 & 3 & 158 & 8.8 & 159 & 16.4 & 161 & 20.3 \\
\hline 15 & 13.25 & 13.00 & 3 & 156 & 10.8 & 158 & 16.2 & 160 & 21.8 \\
\hline 16 & 12.42 & 12.50 & 3 & 150 & 28.6 & 152 & 32.6 & 154.5 & 38.9 \\
\hline 17 & 13.25 & 13.00 & 3 & 154 & 21.7 & 156 & 29.9 & 159 & 36.2 \\
\hline 18 & 12.25 & 12.00 & 3 & 155 & 18.2 & 157 & 23.3 & 159.5 & 29.3 \\
\hline 19 & 12.25 & 12.00 & 3 & 150 & 14.5 & 152 & 26.1 & 154 & 30.2 \\
\hline 20 & 13.42 & 13.83 & 3 & 155 & 12.1 & 157 & 14.8 & 158.5 & 18.2 \\
\hline 21 & 12.33 & 12.00 & 3 & 150 & 22.4 & 152 & 23.6 & 154 & 28.1 \\
\hline
\end{tabular}

KY: Kemik Yaşı; CGE: Cinsel Gelişme evresi; Ost.: Osteokalsin. 
Tablo 2. Her iki cinste: başlangıçdaki, takvim ve kemik yaşı ile 6 ay zarfindaki ortalama boy ve osteokalsin artışı değerleri ve standard hataları

\begin{tabular}{lcc} 
Değişken & $\begin{array}{c}\text { Erkekler } \\
\text { Ort. } \pm \text { SH }\end{array}$ & $\begin{array}{c}\text { Kızlar } \\
\text { Ort. } \pm \text { SH }\end{array}$ \\
\hline Takvim yaşı (yıl) & $13.98 \pm 0.73$ & $12.76 \pm 0.72$ \\
Kemik yaşı (yıl) & $13.97 \pm 0.73$ & $12.76 \pm 0.78$ \\
Boy artışı (cm) & $3.56 \pm 1.80$ & $3.61 \pm 0.99$ \\
Osteokalsin artış $(\mathrm{ng} / \mathrm{ml})$ & $7.08 \pm 5.4$ & $7.46 \pm 4.18$ \\
Vaka sayısı & 23 & 21 \\
\hline
\end{tabular}

Ort.: Ortalama; SH: Standard Hata

\section{Tartışma}

Çalışmamızda serum osteokalsin düzeylerinin erkek vakalarda cinsel gelişme evre 3 ve 4, kızlarda ise evre 2 ve 3 doruğa yükseldiğini tespit ettik. Osteokalsin düzeylerinin altı ay süre ile erkeklerde $7.08 \pm 1.12 \mathrm{ng} / \mathrm{ml}$, kızlarda ise $7.64 \pm 0.95 \mathrm{ng} / \mathrm{ml}$ arttığını tespit ettik. Erkeklerde cinsel gelişme evre 4'ten 5'e, kızlarda ise cinsel gelişme evre 3'ten 4'e geçerken osteokalsi-
Tablo 4. Erkeklerin Tanner evre 3 ve 4, kızların evre 2 ve 3; 6 ay süre ile ortalama boy ve osteokalsin artışı ve standart hata değerleri

\begin{tabular}{lccccc} 
& \multicolumn{2}{c}{ Erkekler } & & \multicolumn{2}{c}{ Kızlar } \\
\cline { 2 - 3 } \cline { 5 - 6 } Değişken & Ort. & SH & & Ort. & SH \\
\hline Boy artışı & 3.50 & 0.24 & & 3.55 & 0.21 \\
Osteokalsin artışı & 7.08 & 1.1 & & 7.64 & 0.95 \\
P değeri & 0.0088 & & & 0.0053 &
\end{tabular}

Ort.: Ortalama; SH: Standard hataları.

nin erişkin düzeyi indiği görüldü.

Kanbur ve arkadaşlarınca ${ }^{[10]}$ osteokalsin düzeyinin erkek çocuklarda boy büyüme hızının doruğunda, cinsel gelişmenin 4 . evresinde, takvim ve kemik yaşı 14 olduğunda doruk düzeylerine eriştiğini, bundan sonra azalmaya başlayarak, evre 4'ten 5'e geçerken anlamlı bir şekilde düştüğü ve erişkin düzeyine indiği de bildirilmiştir.

Bir başka çalışmada Sorva ve arkadaşları ${ }^{[17]}$ takvim yaşı 14 olan 57 sağlıklı erkek adölesanın yıllık büyüme hızı doruğa $(8.9 \mathrm{~cm} /$

Tablo 3. Her iki cinste ortalama takvim yaşı ve cinsel gelişme evrelerine göre ortalama osteokalsin değerleri (ng/ml) \pm Standard hata ve 6 aylık sürede boy ve osteokalsin artı̧̧ değerleri

\begin{tabular}{|c|c|c|c|c|c|c|}
\hline \multirow{2}{*}{$\begin{array}{l}\text { Değişken } \\
\text { Takvim yaşı (yıl) }\end{array}$} & \multicolumn{3}{|c|}{ Erkekler } & \multicolumn{3}{|c|}{ Kızlar } \\
\hline & 13.54 & 13.95 & 14.96 & 12.08 & 12.96 & 13.37 \\
\hline CGE & 3 & 4 & 5 & 2 & 3 & 4 \\
\hline Ortalama Ost. \pm SH & $26.1 \pm 2.32$ & $27.9 \pm 1.92$ & $17.2 \pm 0.83$ & $25.3 \pm 4.27$ & $22.8 \pm 2.4$ & $13.5 \pm 3.16$ \\
\hline Boy artışı \pm SH (cm) & $4.41 \pm 1.02$ & $3.67 \pm 0.66$ & $1.33 \pm 0.57$ & $4.00 \pm 1.00$ & $3.70 \pm 0.64$ & $1.50 \pm 0.70$ \\
\hline Ost. artışı & 9.93 & 7.54 & 0.4 & 7.6 & 8.36 & 2.7 \\
\hline Vaka sayısı (\%) & $6(26.1)$ & $14(60.9)$ & $3(13)$ & $5(23.8)$ & $14(66.7)$ & $2(9.5)$ \\
\hline
\end{tabular}

CGE: Cinsel Gelişme Evresi; Ost.: Osteokalsin; SH: Standard hataları.

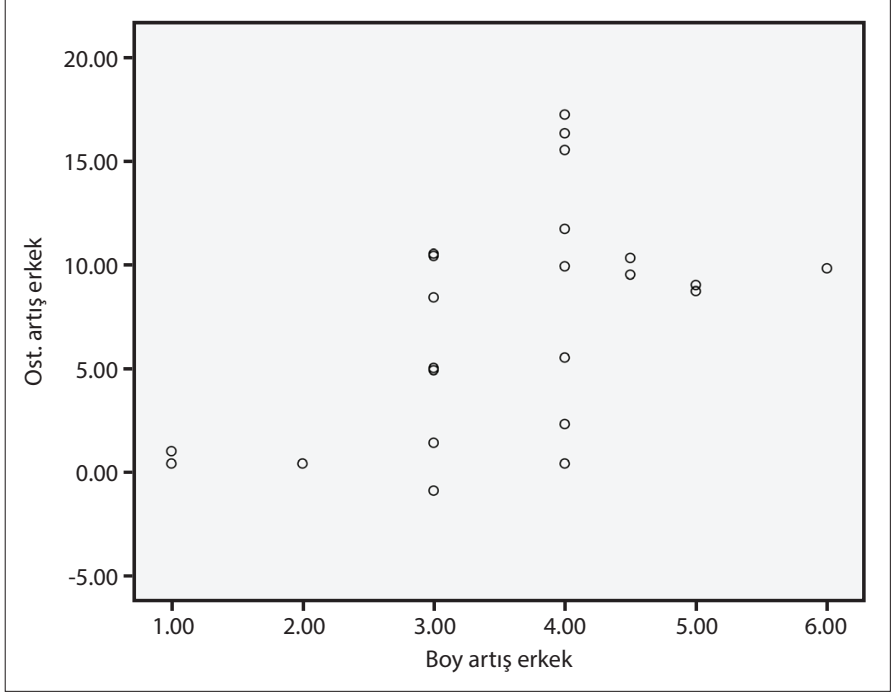

Şekil 1. 6 ay süre ile erkeklerde boy artışı ile osteoklasin artışı arasındaki ilişki gösteren şekil.

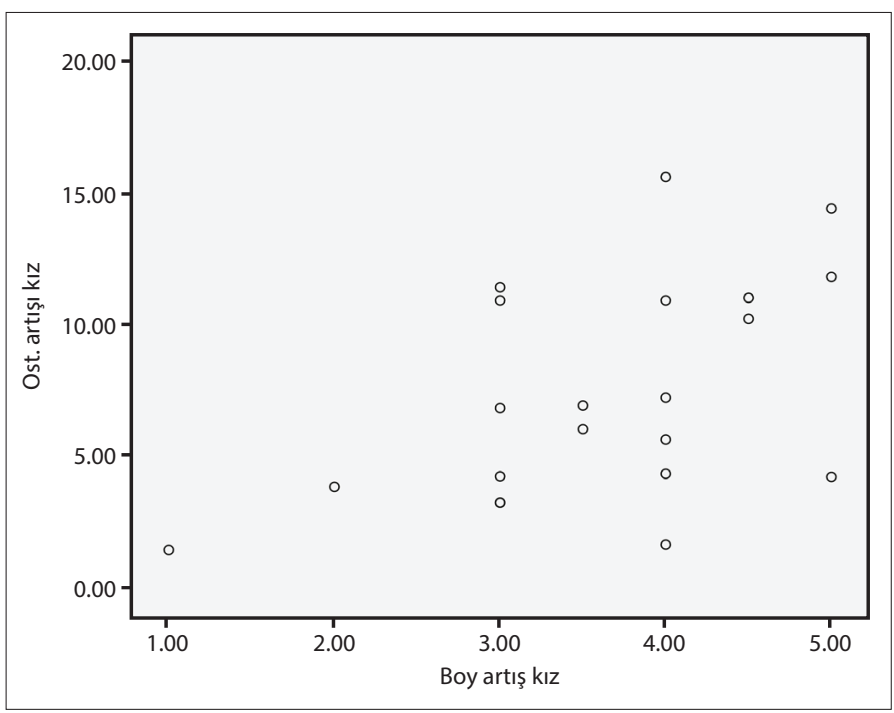

Şekil 2. 6 ay süre ile kızlarda boy artışı ile osteoklasin artışı arasındaki ilişki gösteren şekil. 
yıl) ulaşmış olan ve cinsel gelişmesi evre 4 olan erkeklerin serum osteokalsin düzeylerinin de bu dönemde doruğa çıktığını (50.3 mg/l) bildirmişlerdir. Bu vakaların osteokalsin düzeyleri ile cinsel evreleri 3 ve 5 olan vakaların osteokalsin düzeyleri arasında istatistiksel bir fark olduğunu bildirmişler.

Çalışmamızda, önceki iki çalışmanın ${ }^{[9,17]}$ sonuçlarının benzer olduğunu tespit ettik, bunlara ek olarak çalışmamızda kızlardaki osteokalsin düzeyleri ile büyüme hızındaki değişiklikler incelenmiştir.

Çalışmamızda cinsel gelişme evreleri erkeklerin evre 3 ve 4, kızların ise evre 2 ve 3 iken serum osteokalsin düzeyleri normalden yüksek bulunmuştur (ortalama 26.1 ve $24.05 \mathrm{ng} / \mathrm{ml}$ ). Bu vakaların 6 ay süre ile erkeklerde boy artışı $3.50 \mathrm{~cm}$ olup osteokalsin artış $7.08 \mathrm{ng} / \mathrm{ml}$, kızlarda ise 6 ay süre ile boy artışı $3.55 \mathrm{~cm}$ olup osteokalsin artış $7.64 \mathrm{ng} / \mathrm{ml}$ bulunmuştur. Bu sonuçları Tanner evre 5 olan vakalara göre (boy artışı ortalama $1.33 \mathrm{~cm}$, osteokalsin artışı ortalama $0.4 \mathrm{ng} / \mathrm{ml}$ ) anlamlı bir şekilde daha yüksek idi. Kızlarda ise Tanner evre 4 olan vakalara göre (boy artışı ortalama $1.50 \mathrm{~cm}$, osteokalsin artışı ortalama $2.70 \mathrm{ng} / \mathrm{ml}$ ) anlamlı bir şekilde daha yüksek idi. Vakaların erkeklerde evre 4'ten 5' e geçerken, kızlarda ise evre 3'ten 4'e geçerken boy ve osteokalsin artışlarının belirgin derecede azaldığını gördük. Bu bulgular çalışmamıza dahil edilen vakaların, büyüme doruğunun erkeklerde Tanner evre 3 ve 4, kızlarda ise Tanner evre 2 ve 3'te gerçekleştiği destekliyordu. Bu evrelerde boy artışı paralel olarak osteokalsinin de artığını ve Multiple Regresyon Analizi ile artışın anlamlı olduğunu tespit ettik (Erkeklerde $p=0.0088$, Kızlarda ise $p=0.0053$ ).

Kemiğe spesifik olan, hızlı kemik döngüsü sırasında ve adölesandaki boyca uzama atağı sırasında anlamlı bir şekilde artan, cinsiyet, yaş, ve cinsel gelişme evrelerine göre anlamlı düzeye sahip olup kemik dışı patolojilerden hiç etkilemeyen osteokalsin serum düzeyi ölçümlerinin son zamanlarda klinikte önem kazandığı görülmektedir.

Çalışmamızda osteokalsin düzeylerinin erkeklerde evre 3 ve 4 , kızlarda ise evre 2 ve 3 arasında doruğa ulaştığını tespit ettik. Kızlarda evre 4, erkeklerde ise evre 5 osteoklasin düzeylerinin düşmeye başladığını ve erişkin düzeye ulaştığını belirledik.

Magnusson ve arkadaşlar ${ }^{[11]}$ osteokalsin düzeyinin her iki cinste 11 yaş cıvarında artmaya başladığını, doruğa ulaşmanın kızlarda erkek çocuklardan 2 yıl önce olduğunu bildirmişlerdir, Aynı çalışmada erkek çocuklarda osteokalsin düzeyinin kızlardan 2 yıl daha geç belirgin olarak düştüğünü tespit etmişler ve bunun erkek çocukların büyüme atağı sürecine kızlardan daha geç girmeleri ve erişkin boylarına daha geç ulaşmaları şeklindeki bilgilere uyduğunu belirtmişlerdir.

Literatürde osteokalsin düzeyini konu olan en geniş çalışma 1534 sağlıklı çocuk üzerinde Cioffi ve arkadaşları ${ }^{[10]}$ tarafından yapılmıştır. Büyüme atağı ile birlikte erkek çocuklarda 12 yaşından sonra osteokalsin düzeyinde hızlı bir artış görüldüğü 13 ile 15 yaşları arasında doruk düzeyinde ise hızlı ve belirgin düşüş gözlenmiştir. Bu araştırmanın sonuçları da konu ile ilgili bilgi ve araştırma sonuçlarınımızı destekler özelliktedir.

Çalışmanın kısıtıııkları olarak; çalışmadaki hasta sayısının az ol- ması, izlem başlangııının ileri pubertal evreleri içermesi, izlem sıklığının altı ay gibi kısa bir süre olması ve final boy verisini içermemesi söylenebilir.

Sonuç olarak çalışmamızda adölesandaki yaş, cinsiyet, cinsel gelişme evresi ile osteokalsin düzeyleri arasındaki ilişkilerin literatür verileri ile uyumlu olduğu gösterilmiștir. ${ }^{[9-11]} \mathrm{Her}$ ne kadar vaka sayısı ve izlem süresi yeterli olmasa da birbirini izleyen kontrollerdeki boy artımı ve osteokalsin düzeylerindeki değişimin ilişkili olabileceği şeklindeki öngörümüz gerçekleşmiştir.

Çıkar çatışması: Bildirilmemiştir.

\section{Kaynaklar}

1. Van Coeverden SC, Netelenbos JC, de Ridder CM, Roos JC, Popp-Snijders C, Delemarre-van de Waal HA. Bone metabolism markers and bone mass in health pubertal boys and girls. Clin Endocrinol. 2002;57:107-116.

2. Olmedillas $H$, Gonzalez-Agüero $A$, Rapún-López M, Gracia-Marco L, Gomez-Cabello A, Pradas de la Fuente F, Moreno LA, Casajús JA, Vicente-Rodríguez $\mathrm{G}$. Bone metabolism markers and vitamin $\mathrm{D}$ in adolescent cyclists. Arch Osteoporos. 2018 Feb 3;13(1):11. doi: 10.1007/s11657-018-0415-y.

3. Garanty-Bogacka B, Syrenicz M, Rać M, Krupa B, Czaja-Bulsa G, Walczak M, Sowińska-Przepiera E, Syrenicz A. Association between serum osteocalcin, adiposity and metabolic risk in obese children and adolescents. Endokrynol Pol. 2013;64(5):346-52. doi: 10.5603/EP.2013.0016.

4. Bowden SA, Akusoba Cl, Hayes JR, Mahan JD. Biochemical markers of bone turnover in children with clinical bone fragility. J Pediatr Endocrinol Metab. 2016 Jun 1;29(6):715-22. doi: 10.1515/ jpem-2014-0525.

5. Mills K, Baker D, Pacey V, Wollin M, Drew MK. What is the most accurate and reliable methodological approach for predicting peak height velocity in adolescents? A systematic review. J Sci Med Sport. 2017 Jun;20(6):572-577. doi: 10.1016/j. jsams.2016. 10.012. Epub 2016 Oct 29.

6. Berenbaum SA, Beltz AM, Corley R. The importance of puberty for adolescent development: conceptualization and measurement. Adv Child Dev. Behav. 2015; 48 : 53-92. doi: 10.1016/bs. acdb. 2014.11.002. Epub 2015 Jan 22.

7. De Sanctis V, Elhakim IZ, Soliman AT, Elsedfy H, Elalaily R, Millimaggi G. Methods for Rating Sexual Development in Girls. Pediatr Endocrinol Rev. 2016 Sep;14(1):27-32. doi: 10.17458/PER.2016.

8. James O. Sanders, Xing Qiu, Xiang Lu, Dana L. Duren,Raymond W. Liu, Debbie Dang, Mariano E. Menendez,Sarah D. Hans, David R. Weber, and Daniel R. Cooperman.The Uniform Pattern of Growth and Skeletal Maturation during the Human Adolescent Growth Spurt. Sci Rep. 2017;7:16705. Published online 2017 Dec 1. doi: 10.1038/s41598-017-16996-w.

9. Kanbur NO, Derman O, Sen TA, Kinik E. Osteocalcin. A biochemical marker of bone turnover during puberty. Int J Adolesc Med Health. 2002 Jul-Sep;14(3):235-44.

10. Cioffi M, Molinari AM, Gazzerro P, Di Finizio B, Fratta M, Deufemia A, Puca GA. Serum osteocalcin in 1634 healthy children. Clin 
Chem. 1997 Mar;43(3):543-5.

11. Magnusson P, Häger A, Larsson L. Serum osteocalcin and bone and liver alkaline phosphatase isoforms in healthy children and adolescents. Pediatr Res. 1995 Dec;38(6):955-61.

12. Greulich WW, Pyle SI. Hand Bone Age: A Digital Atlas of Skeletal Maturity in Vicente Gilsanz, Osman Ratib(ed) Springer; Library of Congress. 2005. doi.org /10.1148/radiol.12124026

13. Diamond DA, Paltiel HJ, DiCanzio J, Zurakowski D, Bauer SB, Atala A, Ephraim PL, Grant R, Retik AB. Comparative assessment of pediatric testicular volume: orchidometer versus ultrasound. J Urol. 2000 Sep;164(3 Pt 2):1111-4.

14. Prader A.Testicular size: assessment and clinical importance. Tri- angle1966; 7(6): 240-243.

15. Tanner JM, Whitehouse RH, Takaishi M. Standards from birth to maturity for height, weight, height velocity, and weight velocity: British children. Arch Dis Child. 1966 Dec;41(220):613-35.

16. Tulika Tripathi, Prateek Gupta, Priyank Rai, Jitender Sharma Vinod Kumar Gupta, andNavneet Singh. Osteocalcin and serum insulin-like growth factor-1 as biochemical skeletal maturity indicators. Prog Orthod. 2017; 18: 30. doi: 10.1186/s40510-017-0184-y

17. Sorva R, Anttila R, Siimes MA, Sorva A, Tähtelä R, Turpeinen M. Serum markers of collagen metabolism and serum osteocalcin in relation to pubertal development in 57 boys at 14 years of age. Pediatr Res. 1997 Oct;42(4):528-32. 